\title{
Developing Management Functions in Integrated Pesantren: A Case Study Islamic Boarding School
}

\author{
IndriyatiAdawiyah $^{\mathrm{a}}$, YatimRiyanto ${ }^{\mathrm{b}}$, Karwanto $^{\mathrm{c}}$, Mahmud Tontowi $^{\mathrm{d}}$ \\ a'UniversitasNegeri Surabaya, Jl. Ketintang, Surabaya, Indonesia (indriyati.17070976014@mhs.unesa.ac.id) \\ ${ }^{\mathrm{b}}$ UniversitasNegeri Surabaya, Jl. Ketintang, Surabaya, Indonesia (jatimriyanto@ gmail.com) \\ ${ }^{c}$ UniversitasNegeri Surabaya, J1. Ketintang, Surabaya, Indonesia (karwanto@unesa.ac.id) \\ ${ }^{\mathrm{d}}$ UniversitasNegeri Surabaya, Jl. Ketintang, Surabaya, Indonesia (mahmud.17070976015@mhs.unesa.ac.id)
}

Article History: Received: 10 November 2020; Revised 12 January 2021 Accepted: 27 January 2021; Published online: 5 April 2021

\begin{abstract}
This study aims to describe the implementation of management functions of PondokPesantrenTahfizhPutri (PPTP) at one of the Islamic Boarding School in East Java Indonesia. The Education system integrated with the formal school. The subject of this study are 17 participants. The research method used a qualitative descriptive approach as guidance so that the research focus to describe research's form question or problem identification. Result of the research show that the planning function in its management has long-term planning in vision, mission, and objectives of the foundation. Besides, the organizing function related to the organizational structure.
\end{abstract}

Keywords: Management functions, education system, pesantren (islamic boarding school)

\section{Introduction}

The word "pesantren" is genetically and in its original meaning is used to designate the definition of a residence (dormitory) as well as a place of study used by santri (student in pesantren) with some of its distinctive characteristics compared to other educational institutions [1]. The demand of the society for education in pesantren (Islamic boarding school) from year to year continues to increase because education in pesantren is the most appropriate place to form the character and behavior of children who has akhlaqulkarimah (good character) in facing the challenges of the epoch of the challenge of ideology in Indonesia [2].

The principle of coaching offered by pesantren to students carry out in a balanced way between attitude, character, knowledge, intelligence, ability to communicate, interact with the wider community, and increase awareness of the natural environment in adjusting the development of the eras. The result of pesantren guidance also proves that student in pesantren (santri) besides able to master theology, also have social values, so that many alumni of pesantren become religious figures and public figures. This shows the great potential of pesantren, which is the potential for community development and education by having a strategic position to prepare the human resources that are strong and independent. The existence of the pesantren can play a role as the central potential development of the society, thus making the Islamic boarding school of Indonesia diverse and widespread. The greater the role, the greater the challenge faced by the pesantren [3].

Management in pesantren plays an important and strategic role to achieve educational success. Institutions in pesantren should strive to manage functions well, to trigger more effective processes and educational outcomes. The central role of Kyai as a public figure needs in motivating the pesantren educational institutions to manage, organizing, activating, directing and supervising or controlling [4].

Weaknesses that should be anticipated by pesantren because it has become a strongly embedded tradition such as lack of detailed and rational planning, identical very simple in its management, less directed curriculum, the absence of special standards to differentiate with other education models, facilities and infrastructure are still limited, as well as the hereditary belief that Kyai is who always knows everything. This condition is a challenge that should be improved and looked for solutions gradually to continuously improve the quality of Islamic boarding schools to quality modern education according to the times but not abandoning the tradition of pesantren. Based on Kesuma [5] that a good motto with the term al-muhafazhah 'ala al-qadim al-shalihwa al-akhdzu bi aljadid al-ashlah that is to say, having the principle of nurturing and not abandoning old traditions that are still good and taking on new the better one.

Considering the strategic application of management functions in pesantren, to explore deeper implementation and management processes in pesantren so that they need to be appointed as objects of study. Based on these 
reasons, the researcher conducted a study entitled "Implementation of Management Functions in Integrated Islamic Boarding Schools intends to provide an understanding to all parties about management in Islamic boarding schools". Muntholib et al [6] also said the implementation of this management in terms of management functions, namely: from planning, organizing, and activation or moving up to the process of supervision or control.

PPTP should always perform improvisation and restructuring of pesantren management according to the theory of effective education characteristic and expect to have an effective pesantren characteristic by prioritizing service function, putting forward the quality of education, and accustomed to the tradition of innovation. Although the application is not ideal as the concept of theories because there are many possibilities one of them for limitations [7].

\section{Review of literature}

\section{Pesantren Education}

Pesantren is a cultural system that is different from the environment. Subcultures that are independent and cannot be uniform call pesantren [2]. The implementation of education in pesantren has relatively similar trends, traits, traditions, and educational programs and activities. But, pesantren categorization in Indonesia consists of two forms, namely salafpesantren and modern pesantren [8]. Education in pesantren commonly known to the public can classify in salafy (traditional thought) and khalafy (modern) pesantren. Education in pesantren as a patterned salafy is a system of traditional Islamic education with the characteristics of having elements or components: cottage, mosque, santri, old religious book teaching, and Kyai. While pesantrenkhalafy is a modern pesantren, the traditional pesantren that has transformed the system, traditions, institutions, programs and educational activities [9].

\section{Management of Pesantren}

There are several opinions regarding the notion of management. Management is the process of designing and maintaining an environment in which individuals, working together in groups, efficiently accomplished selected aims" [10]. Lawrence [11] said that the notion of management that management is the art of getting things through people. All this is to determine or achieve the goals that establish through the utilization of human resources, as well as other sources. The action to achieve goals through the efforts of others is management [12]. Besides, Janz and Prasarnphanich [13] said that management is a field of knowledge that systematically seeks to understand why and how people work. Managers coordinate some other people's activities including planning, organizing, moving, and controlling. Understanding management knows as applied science or applicative science that translates into a process of action includes planning or planning, organizing or organizing, moving or actuating, and supervision or control can be seen in Figure 1.

It is through these four stages that management can move and that it also depends on a manager's leadership level. That the managerial process of an organization will move if its managers understand correctly what it does.

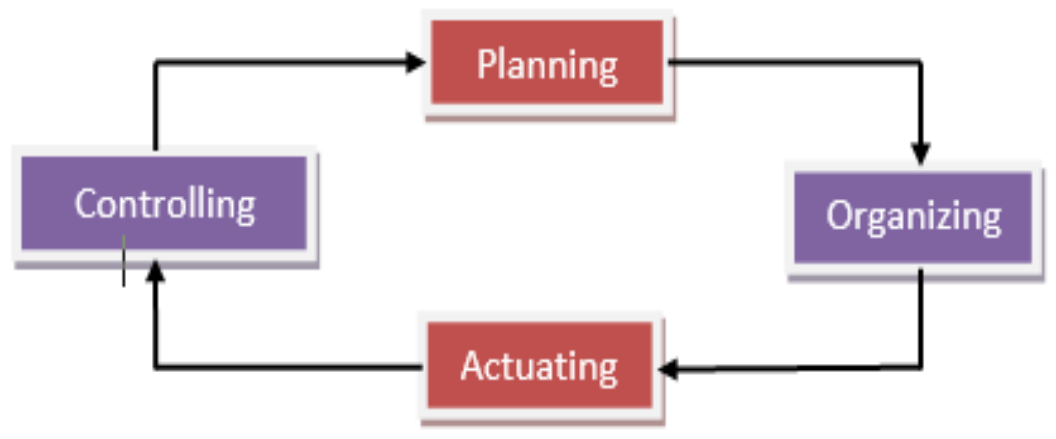

Figure 1. Management functions

Based on the above description can be concluded as seen in Figure 2 that: management can be interpreted as science, tips, and professions in the form of business or action to achieve goals through cooperation by involving the optimal contribution of people, funds, physical, and other sources. 


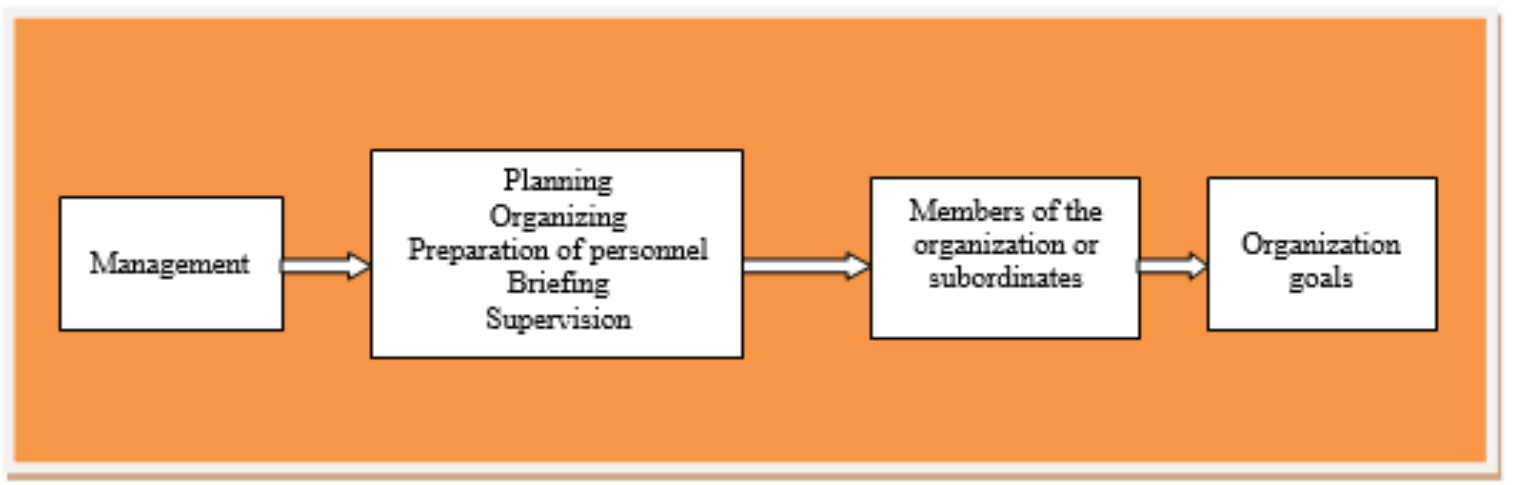

Figure 2. Meaning of management

One weakness of pesantren is in management, so it must motivate by empowering pesantren through coaching [3]. The understanding that pesantren is a traditional educational institution so that in management is not a serious thing to note and very controversial. Management theories as conveyed by management experts, it is agreed that Islamic boarding schools should change the institution's management is to be effective and efficient. Pesantren need management because this field is very important to be studied and developed, that is: without applying good management hence no good boarding institution, set purpose, use human resources and other resources effectively and efficiently, achieve goals or outcomes regularly. Management in pesantren is necessary for the progress and growth of pesantren.

Pesantren as educational institutions that manage educational programs require management to support the achievement of institutional goals, maintain balance, and to achieve efficiency and effectiveness. The success of education in pesantren is influence by the extent to which the manager to process planning, organizing, activation, and supervision or effective control in managing all resources owned. Similarly, the education developed in pesantren also requires management in its implementation, even this aspect is the fundamental and core being the processor in practice. If this aspect is inequality or does not work, it will negatively affect the whole process, program, and activities [14].

The applicative and flexible managerial in managing pesantren direct to the leadership of pesantren as organizing skill, system management including lead, decision, communication, and cooperation which determine the success of expected education [15]. Pesantren in this context requires constructive effort to simulate the various functions of its management so it can support its education plan [16]. It is based on the consideration that general management processes functions are flexible and need flexibility.

\section{Management Function}

Some literature suggests a different understanding of management functions, but has the same essence such as management functions expressed by Griffin as planning, organizing, leadership or leading, and controlling. Intend to argue that leadership has a strong influence on management activities implement properly. Sumarto [17] give opinion is in line with James AF Stoner who put the leading function in place of directing. In summary, the various opinions of management experts in expressing these management functions can see in Figure 3.

\section{Planning}

Planning enables decision-makers to use their human resources efficiently and effectively [18]. All activities of educational organizations in pesantren base on the plan, so that planning is the core of management. Strategic plans meet broader organizational objectives, implementing missions that provide the typical reasons for the existence of the organization, and operational plans describe in more detail how strategic plans will achieve [19].

Participatory planning can use one or a combination of several approaches. One of the thinking process approaches is using a SWOT analysis. The term SWOT is an abbreviation of strength, weakness, opportunity, and treatment. The SWOT approach is identifying the strengths and weaknesses of a condition or problems and good opportunities that exist in that condition to realize the program achieve long-term goals [20].

\section{Organizing}

Organizing is a second function, the purpose of organizing is to divide a large activity into smaller activities. The tasks of an institution through organizing in chapped into smaller parts and then linked to each other and arranged in such a way that gave birth to a unity that goes well. 
Schermerhorn [21] argues that arranging other people and resources to work together in achieving a goal is organizing. The act of seeking effective relationships of behavior among persons need to be done so they can work together efficiently and gain personal satisfaction in performing certain tasks in certain environmental conditions to achieve certain goals and objectives.

\section{Activation or Moving}

After planning, organizing, a leader needs to be able to activate the group efficiently and effectively toward the achievement of goals. These directive efforts to mobilize groups based on established organizations include: communication, leadership, negotiations, instruction giving, and so on. Movement is the effort to move or initiate action and to make the system go towards the goal. Movement is basically a complex management function and the scope is wide enough and closely related to human resources in order to achieve goals with concrete action effectively and efficiently (see Fig.3. some views on management functions). A kyai as the supreme leader in pesantren is not just using traditional rules as a manager in developing its management functions, but also must change to shape the present leadership, the new paradigm rules [22].

The notion of leadership in pesantren is more than a manager, the leadership in pesantren is not only performing the mandated tasks but in the lead must be supplemented by five rules. Drucker said that the rules of paradigm newly identified five rules: visionary or forward-looking servant or can serve, coach or accompany, the facilitator or facilitate, and exemplary. As Drucker points out in Figure 4, that transformational facilitation and leader role are unidirectional. Based on Crane and Patrick [23] there are a role of mentoring is one key to a leader's success.

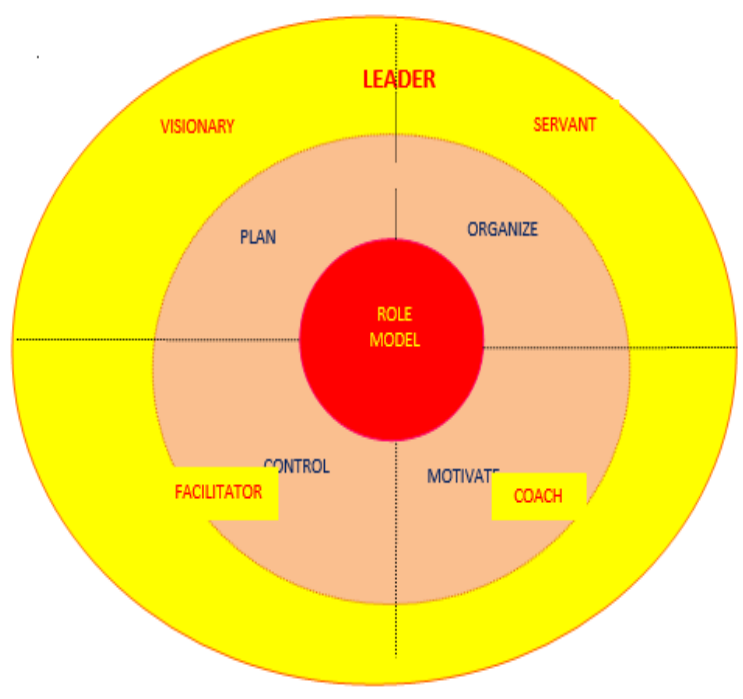

Figure 3. Model circle by Peter Drucker

Most people think leadership is the same as management. The opinion is not true, to be a leader does not have to be a manager. But ideally, a manager is a leader [24][25]. Leaders are not always in an organization, the influence that leaders have because they have more personal ability than others, think of organizations more broadly and long term, have political skills in resolving conflicts, think for progress, improvement of organization widely, and have wider power. Managers are always in a certain organization both formal and non-formal, the influence that managers have because of the formal authority, short-term thinking, limited tasks and responsibilities, using formal-legal approaches, thinking for self-interest and groups narrowly.

\section{Supervision or Control}

Control or evaluation is a process undertaken to ensure that the entire set of planning activities can run under the expected target [26]. As the organization moves, the leader must always supervise the movement or the course of the organization to be fully controlled under the established plan. Plan and execution is a unified action, although this is rare.

According to Schaffer and Thomson [27] give opinion that the plan aims at establishing the appropriate, integrated, and clear. Program objectives while control should set all activities are carrying out under the plan. Supervision or control needs to see how far the results achieved. 


\section{Methods}

This research uses a qualitative approach with a descriptive research type. Refers to the focus and purpose of the proposed research, this research requires an in-depth study to get a detailed and comprehensive description of the contextualization and change of implementing PPTP management functions. The study of the contextualization of this research by involving the active participation of research subjects is stakeholder pesantren concerned. Extensive triangulation or cross-checking is required through interviews, observations, and other documents from various data sources, such as informants in different times and situations. Trying to understand the symptoms that occur in everyday life because of the role of researchers one of them is a key instrument on each data collection. Actions, behaviors, and honestly affect the results of the study.

The research took place at one of the integrated pesantren, PPTP one of The Islamic Boarding School at East Java Indonesia was chosen based on the consideration of its management that can combine with the modern system but still maintain the basic characteristic of pesantren values. Research subjects and informants in this study determined by researchers as much as 17 peoples, mainly one chairman of the foundation (MT), 3 persons of As spiritual guiders (RA, RI, and MC), one person of Boarding school leader (AN), 2 persons of Head of Junior High School and Senior High School (WM and WS), 6 persons of Junior High School Teachers (JA, DM, ST, YI, FZ, and DH), 1 person of Representative Employees (IF), 2 Impartial management person (ZZ and TH), and 1 School Committee (RG).

The existence of this the informant is not fixing but can develop until the data collected is satisfactory, therefore besides using purposive techniques, researchers also use the technique of snowball sampling is the informant can increase until it reaches the level of redundancy (Burges, 1982). Based on the previous description, the data to analyze are the management of pesantren planning, management of pesantren organization, management of pesantern activation, and management of supervision or control pesantren.

The duration of data collection takes about two months. In-depth interviews with informants in the form of questions planned in the interview guide that have been validated by experts, observation takes part through careful observations based on observation guidelines for one month, and documents used in the form of brochures, decisions, program activities, financial budget, photo and video shooting PPTP profile.

Data collection in pesantren for one year previously used to interact with the environment of PPTP since 2013 and often come to make continuous observations about implementing these pesantren management functions. Various angles of data collection methods based on intensive talks with colleagues who directly manage the boarding individually or institutionally through RabithohMa'had Al-Islami (RMI-NU). Consulting with the supervisor to keep the data accuracy and tracking the suitability of all data analysis results through checking the data archive in the form of brochures, decree, activity program, financial budget, photos and a video shot of this pesantren profile collected during field research. The conformity of recording information needs to be checked, interpretation and conclusions of the research by asking the supervisor to review and verify the truth. Checking the truth of researchers in conceptualizing the object under study and quality assessment of research results conducted by two independent auditors. The results of the study are reportedly accurate, describing the context in which the research was conduct regarding the research focus. The readers of this research report can read the results of the research so it can transfer to other contexts.

Under the purpose of research to describe and analyze the functions of PPTP management, it can generate research findings on how the implementation of management functions of PPTP. If the data found the implementation of management functions are not under the existing theory, then this institution needs to fix themselves. If the data is appropriate, then institutions or top leader of pesantren and foundations need to improve themselves to get maximum results. The authors here provide findings on implementing PPTP management.

\section{Results}

\section{The function of planning in PPTP}

Based on data finding in the form of an interview, observation, and documentation, it can describe in the PPTP planning function has been implemented according to the existing theory, because in its management have planned in the vision, mission, and objectives of the foundation as a long-term strategic plan. Strategic planning is made by the foundation that states that strategic plans meet broader organizational objectives, implementing missions that provide the typical reasons for organizational existence and how the strategic plan is achieved.

It also has short-term and medium-term planning. Vision and mission outline in the form of work programs and implementation. Base on the theory, planning is central to management because of all activities of education organizations in pesantren are based on the plan, with planning will enable decision-makers to use their human and human resources efficiently and effectively (Zahari et al., 2018). The plans both short-term and medium-term 
planning are available and only established once on the beginning on pesantren operation. There are no update plans or conducting plans review.

\section{Organizing function in PPTP}

The organizing function in PPTP based on observations in the field already has an organizational structure and plastered on the wall. The process of organizing in performing the task level of managerial structure still double position so that the smoothness of the working mechanism in the process of organizing implementation is not optimal. The division of workload is partially inconsistent with the theory, namely that the organization is done with the aim of dividing a large activity into smaller activities. The tasks of an institution through organizing in into smaller parts and then linked to each other and arranged in such a way that gave birth to a unity that goes well [27]. Hakansson and Snehota [28] argues that arranging other people and resources to work together in achieving a goal is the notion of organizing. In this pesantren the functions of some personnel are still overlapping so that there are some people whose jobs are less than optimal results.

\section{Activation or mobilization function in PPTP}

The activation is an activating and motivating activity in leading or directing. Activation in pesantren is a process of pesantren activities to run in accordance with the planned program. Movement is the effort to move or initiate action and to make the system go towards the goals [29].

The research findings that the activation or mobilization in PPTP is generally already running and in accordance with the theory of mobilization mentioned above, because the caregiver in carrying out activation function by giving motivation in leading or directing subordinates like a family. The caregiver places her position not as a boss as in a company but places herself like a wise leader in a family.

There is a paradigm shift in PPTP to the direction function which cause positive influence for work climate especially in directing personnel not solely depend on kyai figure and it opens opportunity for the party under it can execute management functions directing. In accordance with the above directive theory, that the direction in pesantren is based by the values of worship, exemplary and charism of the kyai. In addition it is revealed that the personal encourage to carry out work discipline that aims to spur performance in addition to religious encouragement is the leadership and exemplary kyai, material needs such as lard in islamic school, as well as a conducive working climate for self-actualization. PPTP has not developed a system of performance awards and achievements that are mutually agreed upon as a basis for directing the entire personal. The briefing activities within this pesantren should be able to continuously encourage their personal to carry out their work based on awareness.

Subsequent findings related to leadership is that the leadership function in PPTP shows the role of top leader of pesantren as the highest leaders in pesantren is influential. The attitude of the caretaker in leading the pesantren has changed the assumption that has been happening in society that charismatic top leader of pesantren usually determine everything, this does not apply in PPTP. The paradigm that was built in this pesantren is to convert pesantren with modern and professional system by not leaving the basic characteristics of pesantren. A kyai as the supreme leader in pesantren is not just using traditional rules as a manager in developing his management functions, but also has to change to form the present leadership, that is the new paradigm rule.

The definition of leadership in pesantren is more than just a manager, the leadership in pesantren not only performs the tasks that are ordered, but in the lead must be supplemented by five rules, namely forward-looking, serving, assisting, facilitating and exemplary. Drucker said that the new paradigm rules identified there are five rules: visionary or forward-looking, servant or can serve, coach or accompany, facilitator or facilitate and exemplary (as cited in Crane \& Patrick, 2002).

This is an interesting finding because generally in a pesantren, a kyai is very central and in full control or has high power. But in this PPTP there are a number of kyai whose tasks have been arranged with the system. Some of these kyai are incorporated in the caregiver council whose arrangements have been established.

Another finding that needs to be considered is the absence of a system that regulates respect for personnel who have good work. Of course as motivation, this award system is important to improve the quality of performance.

\section{Function of Supervision or Control in PPTP}

The control or evaluation function engage in the PPTP is a process to ensure that all planned, organized and implemented a series of activities are in line with the intended target. As the organization moves and moves, the leader must always supervise the movement or the course of the organization to be fully controlled under the established plan, on the direction and the way. Plan and execution is a unified action, although this is rare. 
Base on the research findings that the aspects of supervision or control of PPTP relating to the reporting and evaluation of pesantren activities that have done made periodically have done running but not optimal so that when conducting the program, the follow-up activities cannot be immediate. Without supervision or control of the top leader of pesantren then the planning that has done made it will not achieve the goal. According to Billy's opinion that the plan is aimed at establishing the appropriate, integrated and clear program objectives, while control is intended to set all activities to be carried out in accordance with the plan. Supervision or control is needed to see how far the results are achieved.

\section{Discussion}

Based on the results of data about the existence of planning in PPTP, there are already has the plans, both short and long term plans. The Foundation has conducted the examination of strategic issues in strategic planning analyzed by utilized SWOT analysis approach. The SWOT approach is identifying the strengths and weaknesses of a condition or problem and the good opportunities that exist in the condition to realize the program to achieve long-term goals [20]. This analytical approach conduct to advance the pesantren in identifying potentials or strengths, weaknesses, exploiting existing opportunities and facing challenges to realize the program to achieve the long-term goals of this educational institution. It's just that the review of planning with this SWOT analysis is no longer done. Only done once at the beginning of the foundation. SWOT analysis should be reviewed every few years to ascertain whether there are changes in some conditions. if there is a change, of course the existing planning needs to be revised to adjust to the latest conditions.

The relationship with the organizing function, there must be clarified some tasks for several people, especially at the structural level of the organization. The overlapping work must be reduced. The foundation must take action to review existing conditions. It is time to review the placement of personnel at the managerial level in order to reducing overlapping task and getting optimum organization. Kyai is a central figure in a pesantren. So in fact it would be very effective if the guidance council consisting of a number of kyai in the Islamic boarding school was directing the managerial level below it like a school principal and boarding leader.

The act of seeking effective relationships of behavior among persons needs to be done so that they can work together efficiently and gain personal satisfaction in performing certain tasks in certain environmental conditions to achieve certain goals and objectives [26]. Organizing in the implementation of work program functional level of the teachers' council has been carrying out teaching tasks in accordance with the authority and responsibility of their respective areas of expertise [30].

The findings related to the activation and mobilization function are two things. First, the existence of a system that regulates the authority of the kyai who are members of the caregiver council. Usually the task of the kyai is very powerful, not through the system. But in this PPTP the duties of the kyai are arranged through a system created by the foundation. Second, about the leadership of the kyai it is very different from leadership in general. The spiritual touch is very prominent in running an organization in a pesantren. Kyai gives many advices and role models for santri in the environment pesantren.

Kyai's leadership in PPTP is not the same as corporate leadership. As per the opinion that the leader is different from the manager. Leaders are not always in an organization, can be appointed or appointed by their members, the influence that leaders have because they have more personal ability than others, think of organizations more broadly and long term, have political skills in resolving conflicts, think for progress and improvement of organization widely, and have wider power. Managers are always in a certain organization both formal and nonformal, always appointed, the influence that managers have because of the formal authority, short-term thinking and limited tasks and responsibilities, using formal legal approaches, thinking for self-interest and groups narrowly, have authority only.

Another to be consider, it's about awards for performance and achievements. It should be held in the direction that the PPTP has not yet developed a system of performance awards and achievements that are mutually agreed upon as the basis for directing the whole person. Cooperation between top leader of pesantren and foundations, and santri guardian assemblies and teacher councils and tutor councils are excellent.

Based on the findings of others, that top leader of pesantren in carrying out supervisory or control functions is very important. The steps or forms of supervision or control carried out by the top leader of pesantren are Kyai and foundations to analyze the work program, then discussed at the level of pesantren institutions through halaqah or plenary meeting all components of boarding school including santri guardian assembly. If approved and agreed upon, then the work program is passed into the work program of PPTP. The process of the steps undertaken by the top leader of pesantren is supervision or control of the initial level. For supervision or control of the ongoingpesantren programs, such supervision or control is carried out by direct supervision or control and 
oversight or indirect control, and supervision or joint control. The subsequent findings show that implementing supervision or control of management is not entirely the authority of Kyai as the leader of pesantren.

Even the process of supervision or control carried out jointly in a halaqah forum is an evaluation of the implementation, the results achieve and the constraints that arise. Major motivational efforts provide from board leaders ranging from a top leader of pesantren, foundations, to coordinators in implementing predetermined program activities and reporting on the results of implementing the program activities review and more likely to focus on efforts to test program- any activity programs that are still eligible to be forwarded, deleted, reduced, supplemented or enhanced. Plan and execution is a unified action, although this is rare. The theory that supervision or control needs to see how far the results achieve. The leadership of PPTP does not yet have a mechanism or guidance in carrying out supervision or control, so that in performing supervisory or controlling functions do not use guidance. How to fix is a mechanism or guidance of the supervisory system.

\section{Conclusion}

The planning function in its management has had long-term planning in the vision, mission, and objectives of the Foundation. Organizational functions related to the organizational structure create and advertised on the wall. Powers and responsibilities implement, but in implementing managerial-level tasks there are still dual positions so that the smooth running of work mechanism in organizing implementation is less than optimal. Implementation of work program functional level of the board of teachers in carrying out teaching tasks under their respective areas of expertise. Functions of activation or mobilization include motivation, direction, and leadership. But, has not developed a system of performance awards and achievements that agree upon. Cooperation between the top leaders of pesantren and foundations and santri guardian assemblies and teacher councils and tutor councils are underway. The function of supervision or control related to the reporting and evaluation of pesantren activities which make periodically is running but not optimal so that when conducting the program the follow-up activities cannot be done immediately. The top leader of pesantren in carrying out supervisory or control functions work. Although in the reporting the implementation of pesantren activities are made periodically and carried out in an orderly manner but have no mechanism or guidance in implementing such supervision or control so that the leadership in PPTP in performing this management function does not use guidance.

\section{References}

Herlina, N. H. (2016). The Transformation of Traditional PondokPesantren to Modern Orders. International journal of educational studies, 13(1), 7-19

Hafidh, Z., \&Badrudin, B. (2018).PesantrendanKemandirianPerekonomian: StuditentangKewirausahaan di PondokPesantrenAr-RisalahCijantung IV Ciamis. Manageria: JurnalManajemenPendidikan Islam, 3(2), 257267.

Idham. (2016). Empowerment of santri in reality and recollection: Study in PesantrenHubulo. JurnalPendidikan Islam, 5(2), 235-259.

Alam, N. A. R. (2018). Strengthening Leadership Culture (The Role of Kyai in Indonesian Pesantren). AtTa'dib, 13(1), 5-17

Kesuma, G. C. (2017). Refleksi PendidikanPesantrendanTantangannyaMasaKini.TadrisJurnalKeguruandanIlmuTarbiyah, 2, 63-74.

Muntholib, Maisah\&Maryani.(2018). Management of pesantren in development of Islamic religion education.International journal of research Granthaalayah, 6(9), 407-420.

Humaisi, M. S., Thoyib, M., Arifin, I., Imron, A., \&Sonhadji, A. (2019).Pesantren education and charismatic leadership: a qualitative analysis study on quality improvement of islamic education in pondokpesantrennuruljadid (Indonesia). Universal Journal of Educational Research, 7(7), 1509-1516

Ashari, M. S. (2019). Pesantren di tengahgempuransekolah modern.WahanaIslamika: JurnalStudiKeislaman, 5(1), 116-138.

Rahayani, Y. (2017). Restructuring and redesigning the pesantren toward an efective educational institution. TARBIYA: Journal of Education in Muslim Society, 4(2), 114-127

Adeoti, O., George, O., \&Adegboye, M. (2013). Management thought and philosophy. Global Advanced Research Journal of Social Science (GARJSS), 2(9), 212-220.

Lawrence, A. (1969). Appley: Management in Action-The Art of Getting Things Done Through People. The Times of India Press, Bombay, 19.

Van der Hoek, M., Groeneveld, S., \&Kuipers, B. (2018). Goal setting in teams: Goal clarity and team performance in the public sector. Review of public personnel administration, 38(4), 472-493.

Janz, B. D., \&Prasarnphanich, P. (2003).Understanding the antecedents of effective knowledge management: The importance of a knowledge-centered culture.Decision sciences, 34(2), 351-384.

Benaziria, \&Murdiono, M. (2019). Civic teacher strategy in the integration of nationalism and tolerance character in school based on pesantren in yogyakarta city. Journal of Social Studies (JSS), 15(1), 9-26 
Luthra, A., \&Dahiya, R. (2015). Effective leadership is all about communicating effectively: connecting leadership and communication. International Journal of Management \& Business Studies, 5(3), 43-48.

Munjin. (2018). The System of Educational Quality Management. Institut Agama Islam Negeri (IAIN): STAIN Press

Sumarto, S. (2017).Equalization and Standardization of Management of Education in Madrasah. HUNAFA: JurnalStudiaIslamika, 14(1), 117-139.

Silva, M. S. A. E., \& Lima, C. G. D. S. (2018).The Role of Information Systems in Human Resource Management. Management of Information Systems (InTech), 113-126.

Handoko, T. (2003).Management Edition 2. Yogyakarta: BPFE.

Gürel, E., \& Tat, M. (2017). SWOT analysis: a theoretical review. Journal of International Social Research, $10(51)$.

Schermerhorn Jr, J. R. (1979). Interorganizational development. Journal of Management, 5(1), 21-38.

Hao, M. J., \&Yazdanifard, R. (2015). How effective leadership can facilitate change in organizations through improvement and innovation. Global journal of management and business research. 15(9), 1-6.

Crane, T. G. (2010). The heart of coaching. FTA press.

Siswono, T. Y. E., Hartono, S., Kohar, A. W., Karim, K., \&Lastiningsih, N. (2019). How do Prospective Teachers Manage Students' Learning of Mathematics?.TEM Journal, 8(2), 677.

Iswahyudi, P., Dewie, T. W., Soedjarwo, S., \& Hartono, S. (2019). Influence of Graduation Quality and Flight Training as a Vocational School on International Standard Job Opportunities.TEM Journal, 8(4), 1456.

Siswono, T. Y. E., Kohar, A. W., \& Hartono, S. (2018, January). Designing Tasks to Examine Mathematical Knowledge for Teaching Statistics for Primary Teachers. In Journal of Physics: Conference Series (Vol. 947, No. 1, p. 012008). IOP Publishing.

Schaffer, R. H., \& Thomson, H. A. (1992). Successful change programs begin with results. Harvard business review, 70(1), 80-89.

Håkansson, H., \&Snehota, I. (2006). No business is an island: The network concept of business strategy. Scandinavian journal of management, 22(3), 256-270.

Richards, J. C. (2013). Curriculum approaches in language teaching: Forward, central, and backward design. Relc Journal, 44(1), 5-33.

Darling-Hammond, L., Flook, L., Cook-Harvey, C., Barron, B., \&Osher, D. (2020).Implications for educational practice of the science of learning and development.Applied Developmental Science, 24(2), 97-140. 